\title{
Shading of stock plants and the use of auxin in red pitaya cuttings
}

\section{Sombreamento de plantas matrizes e uso de auxina na estaquia de pitaia vermelha}

\author{
Edmilson Igor Bernardo Almeida ${ }^{1 *}$; Ronialison Fernandes Queiroz²; João Paulo \\ Cajazeira $^{3}$; Iana Maria de Souza Oliveira ${ }^{4}$; Márcio Cleber de Medeiros Corrêa ${ }^{5}$
}

\begin{abstract}
Although there has been a significant expansion of red pitaya cultivation in Brazil and other countries around the world, its cultivation requires scientific expertise to identify the plant production systems best suited to Brazilian soils and climate. Therefore, this study aimed to evaluate the effect of exogenous auxin and shading of the parental stock plants on the subsequent quality of red pitaya cuttings. The use of a commercial rooting auxin (with and without) and five shading levels on stock plants (full sun, $35,50,65$ and $80 \%$ shading) were tested via four randomized blocks in a factorial $2 \times 5$ scheme with two plants per plot. After 90 days, the following vegetative characteristics were evaluated: length of the longest root (LR), root dry mass (RDM), root width (RW), shoot fresh weight (SFW) and shoot dry weight (SDW), total dry weight (TDW), number of axillary shoots (NAS), sum of the length of the axillary shoots (SLAS), and shoot:root ratio (SRR). We concluded that for the production of high quality plants, collecting cuttings from stock plants grown in full sun or $80 \%$ shade is recommended, eliminating the need to use commercial rooting auxin.
\end{abstract}

Key words: Cladodes. Rooting. Exotic fruits. Hylocereus spp. Growth regulator.

\section{Resumo}

Embora tenha ocorrido grande expansão no cultivo de pitaia vermelha tanto no Brasil como em outros países do mundo, a cultura necessita de informações científicas que subsidiem a definição de sistemas de produção de mudas mais adequados às condições edafoclimáticas brasileiras. Diante disso, objetivou-se avaliar o efeito de auxina exógena e sombreamento das plantas matrizes sobre a qualidade de mudas de pitaia vermelha. Foram testados o uso de enraizador comercial (presença e ausência) e cinco níveis de sombreamento nas plantas matrizes (pleno sol, 35, 50,65 e 80\% de sombreamento), os quais foram arranjados em fatorial $2 \times 5$, com quatro blocos casualizados e duas plantas por parcela. Aos 90 dias, avaliaram-se as seguintes características vegetativas: comprimento da maior raiz (CR), massa seca das raízes (MSR), largura radicular (LR), massa fresca (MFPA) e seca da parte aérea (MSPA), massa seca total (MST), número de emissões laterais (NEL), somatório do comprimento de emissões laterais (SCEL) e razão parte aérea-raiz (RPAR). Para a produção de mudas de boa qualidade recomenda-se a coleta de estacas em plantas matrizes cultivadas a pleno sol ou $80 \%$ de sombra, sem a necessidade de enraizador comercial.

Palavras-chave: Cladódios. Enraizamento. Frutíferas exóticas. Hylocereus spp. Regulador de crescimento.

\footnotetext{
${ }^{1}$ Prof. Adjunto, Centro de Ciências Agrárias e Ambientais, Universidade Federal do Maranhão, UFMA, Campus Chapadinha, Chapadinha, MA, Brasil. E-mail: edmilson_i@hotmail.com

${ }^{2}$ Bolsista de Pós-Doutorado PNPD/CAPES, Departamento de Fitotecnia, Centro de Ciências Agrárias, Universidade Federal do Ceará, UFC, Fortaleza, CE, Brasil. E-mail: ronialison@hotmail.com

${ }^{3}$ Doutor em Agronomia (Fitotecnia) pelo Programa de Pós-Graduação em Agronomia (Fitotecnia), Centro de Ciências Agrárias, UFC, Fortaleza, CE, Brasil. E-mail:jp_caja@yahoo.com.br

${ }^{4}$ Discente do Curso de Graduação em Agronomia, Centro de Ciências Agrárias, UFC, Fortaleza, CE, Brasil. E-mail: ianamaria_ oliveira@hotmail.com

5 Prof. Associado, Departamento de Fitotecnia, Centro de Ciências Agrárias, UFC, Fortaleza, CE, Brasil. E-mail: mcleber@gmail.com

* Author for correspondence
} 


\section{Introduction}

The red pitaya (Hylocereus spp.) is a cactaceous fruit from a semi-epiphytic plant with star-shaped modified stems, called cladodes. The root system is fasciculated and superficial, but the plant may also develop adventitious roots that grow along the length of the cladodes in order to assist in securing it to support structures (DONADIO, 2009; MIZRAHI, 2014). Originally from the Americas, it has expanded into Brazil and is considered to be an exotic fruit with high agronomic and economic potential (JUNQUEIRA et al., 2010; LE BELLEC et al., 2006; ORTIZ-HERNÁNDEZ; CARRILLOSALAZAR, 2012).

The cultivation of red pitaya in Brazil is recent, beginning fifteen years ago in the state of São Paulo. From this period onwards, its cultivation has expanded and currently there are commercial areas in Minas Gerais, Paraná, Santa Catarina, Mato Grosso do Sul, Rio Grande do Norte, Ceará and Pernambuco (SILVA, 2014). In Ceará, production is mainly concentrated in Limoeiro do Norte and Quixeré. Cultivation areas are recent, in an agronomic management improvement phase, and profitable for commercial exploitation (NUNES et al., 2014).

The propagation of red pitaya is usually asexual via cuttings. Plants produced from this method result in an early yield and create uniform plantations in terms of their phenological characteristics and desirable fruit quality (ANDRADE et al., 2007; GALVÃO, 2015; SILVA et al., 2011). Lima (2013) and Marques et al. (2011) found that Hylocereus undatus propagules produced from cuttings of 25 centimeters $(\mathrm{cm})$ long rooted better than those of a shorter length.

Pontes Filho et al. (2014) added that the use of $3000 \mathrm{mg} \mathrm{L}^{-1}$ of $\alpha$-aminoisobutyric acid (AIB) enhanced the rooting quality of $H$. undatus cuttings $25 \mathrm{~cm}$ in length. However, it is important to note that information on the use of commercial growth regulators is minimal (BARROSO, 2014). Research on this subject may have practical applications and facilitate nursery operations for the production of Hylocereus sp. propagules.

In some vegetable species, cultivation of stock plants and the rooting of cuttings should be carried out under low radiation (DUTRA et al., 2012; HARTMANN; KESTER, 1990). According to Johnson and Hamilton (1977), high light intensities in the cultivation environment can activate the AIA-oxidase enzyme system that destroys auxin, reducing the rooting potential of cuttings collected from stock plants cultivated in full sun.

Under natural conditions, the red pitaya is found in the shaded rainforest understories of America, which suggests that when grown commercially it is necessary to install a system of protection against exposure to direct sunlight (NOBEL; DE LA BARRERA, 2004). Within this context, preliminary studies were performed in Israel (MIZRAHI; NERD, 1999) and Brazil (CAVALCANTE et al., 2011) which confirmed the need for 30 to $60 \%$ shading, depending on local conditions.

However, most of Brazil's commercial orchards are grown in full sun. To date, the effects of full exposure to solar radiation on the productive capacity of plants and the quality of rooting in cuttings collected from them remain unknown. Based on the above, this study was conducted in order to assess the effect of the use of auxin and shading on red pitaya stock plants by evaluating the subsequent quality of their cuttings.

\section{Material and Methods}

The experiment was conducted for a duration of 90 days, from August to November 2014, in a greenhouse with a light intensity of $550 \mu \mathrm{mol}$ photons $\mathrm{m}^{-2} \mathrm{~s}^{-1}$ located in the horticulture sector of the Department of Plant Science, Agricultural Science Center of the Federal University of Ceará in Fortaleza (CE) (3'43'02 "S latitude and 38'32'35" WGR longitude, elevation 19.6 m) (IPECE, 2011). 
According to the Köppen (1918), the climate is Aw. This is a region belonging to the tropical rainy climate group, with an average annual temperature of $26.5^{\circ} \mathrm{C}$.

The experimental design was a $2 \times 5$ factorial randomized block design (RBD), with four replications and two plants per plot. The first factor represents the presence or absence of rooter, and the second factor represents shading levels in the stock plants (full sun, 35, 50, 65 and 80\% shading). The commercial rooting compound used was Sela Gel®, comprised of 3,000 $\mathrm{mg} \mathrm{L}^{-1}$ of AIB. The dose of AIB applied was based on recommendations by Barroso (2014), Bastos et al. (2006) and Pontes Filho et al. (2014), for Hylocereus sp.

The cuttings were collected from plants 380 days old grown under different levels of light radiation (full sun, 35, 50, 65 and 80\% shading) in plastic $11 \mathrm{~L}^{-1}$ pots. The propagation material used for the production of cuttings was selected based on health, vigor, and position relative to the apex (secondary and/or tertiary buds), with an average length of 25 cm, as recommended by Lima (2013), Marques et al. (2011), Pontes Filho et al. (2014) and Silva (2014).

After cuttings were collected, they were washed under running water and exposed to ambient drying conditions $\left( \pm 25^{\circ} \mathrm{C}\right.$ and $\left.\pm 70 \% \mathrm{RH}\right)$ for 60 minutes. Afterwards, cross-sections were made in the basal portion of the cuttings, enabling exposure of internal tissues to the exogenous auxin solution. The application of the commercial rooting gel was carried out by dipping the basal end of the cuttings in the solution for 3 seconds, followed by a 10-minute rest period before planting, as per the manufacturer's recommendations.

The remaining cladodes were immersed in distilled water and immediately planted in $3 \mathrm{dm}^{3}$ polyethylene bags filled with sandy soil and coconut shell powder at a ratio of $2: 1$, for which the chemical analysis is shown in Table 1. The application of $187.50 \mathrm{mg} \mathrm{L}^{-1}$ of P (ALMEIDA, 2013; ALMEIDA et al., 2014; CORRÊA et al., 2014) was carried out in the form of simple superphosphate $\left(18 \% \mathrm{P}_{2} \mathrm{O}_{5}\right.$, $16 \% \mathrm{Ca}$ and $8 \% \mathrm{~S}$ ). The maintenance of moisture in the substrate during the trial period was performed by hand watering at two-day intervals.

Table 1. Chemical characteristics of the substrate used to fill the bags. Fortaleza (CE), 2014.

\begin{tabular}{cccccccccccccc}
\hline M.O. & $\mathrm{pH}$ & $\mathrm{P}$ & $\mathrm{K}^{+}$ & $\mathrm{Ca}^{2+}$ & $\mathrm{Mg}^{2+}$ & $\mathrm{Na}^{+}$ & $\mathrm{Al}^{3+}$ & $\mathrm{H}^{+}+\mathrm{Al}^{3+}$ & $\mathrm{S}$ & $\mathrm{T}$ & $\mathrm{V}$ & $\mathrm{C}$ & $\mathrm{N}$ \\
\hline $\mathrm{g} \mathrm{kg}^{-1}$ & & $\mathrm{mg} \mathrm{kg}$ & & $\ldots \ldots \ldots \ldots \ldots \ldots \ldots \ldots \ldots \ldots \ldots \mathrm{cmol}_{\mathrm{c}}$ & $\mathrm{kg}^{-1} \ldots \ldots \ldots \ldots \ldots \ldots \ldots \ldots \ldots \ldots \ldots$ & & $\%$ & $\ldots \ldots . \mathrm{g} \mathrm{kg}^{-1} \ldots \ldots$ \\
22.9 & 5.2 & 6.00 & 0.28 & 1.00 & 1.00 & 0.46 & 0.28 & 3.1 & 2.7 & 5.9 & 45.8 & 22.2 & 2.1 \\
\hline
\end{tabular}

Extractors: $\mathrm{P}, \mathrm{Na}$ and $\mathrm{K}-$ Mehlich; $\mathrm{Ca}, \mathrm{Mg}$ and $\mathrm{Al}-\mathrm{KCl}$; $\mathrm{H}+\mathrm{Al}-$ Calcium acetate; $\mathrm{pH}-$ Water.

After 90 days, the following vegetative characteristics were evaluated: survival and rooting - determined by the qualitative assessment of the cuttings at the end of the experiment, with the results expressed as the percentage of rooted cuttings to total planted cuttings (\%); length of longest root (LR) - measured with a millimeter tape from the insertion region of the root system to the terminal end of the longest root, with the results expressed in $\mathrm{cm}$; root width (RW) - measured with a digital caliper in the transverse direction to the root system, with the results expressed in $\mathrm{cm}$; root dry mass (RDM) - measured by weighing the dried roots in a forced air greenhouse $\left(65^{\circ} \mathrm{C}\right)$ for 120 hours, the results of which were expressed in grams (g); shoot wet mass (SWM) - measured by weighing the axillary shoots (fresh), the results of which were expressed in g; shoot dry mass (SDM) - measured by weighing the dry axillary shoots in a forced air greenhouse $\left(65^{\circ} \mathrm{C}\right)$ for 120 hours, the results of which were expressed in g; total dry mass (TDM) - determined by the sum of the shoot dry mass and 
root dry mass, the results of which are expressed in g; number of axillary shoots (NAS) - measured by counting the axillary budding, with the results expressed in numerical units; the sum of the length of the axillary shoots (SLAS) - determined by the sum of the length of the axillary shoots, which were measured with a millimeter tape in the longitudinal direction of each cladode, with the results expressed in $\mathrm{cm}$; shoot:root ratio (SRR) - estimated by the ratio of SLAS to LR.

Data were submitted to an analysis of variance (F-test with significance level $p<0.05$ ) in order to assess the main effects of each variable (A and $\mathrm{B})$ and interaction between variables (A $\mathrm{x} B$ ). The comparison of means was performed using the Tukey test for the qualitative factor $(p<0.05)$ and regression to the quantitative factor (linear model: $\mathrm{a}+\mathrm{bx}$; quadratic model: $\mathrm{a}+\mathrm{bx}+\mathrm{CX}^{2}$ ). For meaningful interaction, it was proceeded the split of the means and the interpretation of the effect of one variable on another.

Estimates of phenotypic correlations were obtained for most traits evaluated, considering all of them were important for the study.

\section{Results and Discussion}

The interaction between rooting compound and shading levels on stock plants caused a significant effect $(p<0.01)$ on LR, SLAS, SDM, TDM and SRR. The SWM was affected by two factors alone $(p<0.05)$, whereas RW and RDM were influenced only by the rooting compound $(\mathrm{p}<0.01)$ (Tables 2 and 3).

Table 2. Summary of the analysis of variance for the following characteristics at 90 days: length of the longest root (LR), root width (RW), dry root mass (DRM), sum of the length of axillary shoots (SLAS), number of axillary shoots (NAS).

\begin{tabular}{|c|c|c|c|c|c|c|}
\hline \multirow{2}{*}{ SV } & \multirow{2}{*}{ DF } & \multicolumn{5}{|c|}{-------------------------- Average squares ------------------------- } \\
\hline & & LR & RW & DRM & SLAS & NAS \\
\hline Rooting compound (R) & 1 & $0.6052^{\mathrm{ns}}$ & $14.1016^{* *}$ & $7.1635 * *$ & $20.1924 *$ & $0.2250^{\mathrm{ns}}$ \\
\hline Shading (S) & 4 & $27.2309 * *$ & $1.1352^{\mathrm{ns}}$ & $0.3509^{\mathrm{ns}}$ & $58.7764 * *$ & $0.1000^{\text {ns }}$ \\
\hline $\mathrm{R} \times \mathrm{S}$ & 4 & $15.0559 * *$ & $1.7070^{\mathrm{ns}}$ & $0.2320^{\mathrm{ns}}$ & $32.0288 * *$ & $0.1000^{\mathrm{ns}}$ \\
\hline Blocks & 3 & $21.1926^{* *}$ & $2.2099 *$ & $0.0696^{\mathrm{ns}}$ & $3.2348^{\mathrm{ns}}$ & $0.0417^{\mathrm{ns}}$ \\
\hline Residue & 27 & 3.2175 & 0.7064 & 0.1646 & 3.3378 & 0.0787 \\
\hline C. V. & & 6.09 & 6.77 & 15.13 & 13.54 & 26.10 \\
\hline
\end{tabular}

SV - Source of variation; DF - Degree of freedom; C.V. - Coefficient of variation; - Significant at a level of $5 \%$ by the F test; ** - Significant at a level of $1 \%$ of probability by the $\mathrm{F}$ test; ${ }^{\text {ns }}-$ Not significant by the test $\mathrm{F}$.

Table 3. Summary of the analysis of variance for the following characteristics at 90 days: shoot wet and dry mass (SWM and SDM), total dry mass (TDM) and shoot:root ratio (SRR).

\begin{tabular}{cccccc}
\hline \multirow{2}{*}{ SV } & \multirow{2}{*}{ DF } & \multicolumn{3}{c}{----------------------- Average squares ----------------------- } \\
\cline { 3 - 5 } & & MFPA & MSPA & MST & RPAR \\
\hline Rooting compound (R) & 1 & $58.5398^{*}$ & $0.5869^{\text {ns }}$ & $12.1728^{* *}$ & $0.0205^{*}$ \\
Shading (S) & 4 & $280.00753^{* *}$ & $3.7562^{* *}$ & $10.2289^{* *}$ & $0.0797^{* *}$ \\
R x S & 4 & $26.4301^{\text {ns }}$ & $1.2765^{* *}$ & $4.9787^{* *}$ & $0.0259^{* *}$ \\
Blocks & 3 & $33.2011^{\text {ns }}$ & $0.1723^{\text {ns }}$ & $0.1159^{\text {ns }}$ & $0.0069^{\text {ns }}$ \\
Residue & 27 & 13.5838 & 0.1744 & 0.2998 & 0.0033 \\
C. V. & & 12.01 & 13.81 & 9.60 & 13.76 \\
\hline
\end{tabular}

SV - Source of variation; DF - Degree of freedom; C.V. - Coefficient of variation; - Significant at a level of 5\% by the F test; ** - Significant at a level of $1 \%$ of probability by the F test; ${ }^{\text {ns }}$ - Not significant by the test F. 
Rooting and survival for all treatments was $100 \%$, similar to the results obtained by Bastos et al. (2006), Marques et al. (2011, 2012) and Pontes Filho et al. (2014), for $H$. undatus cuttings grown in polyethylene bags under lath and greenhouse.

The increase in shading on stock plants and the non-application of a rooting compound resulted in a quadratic adjustment of LR values, represented by a decline between full sun and $65 \%$ shading, and an increase from 65 to $80 \%$ shading (Figure 1). It is likely that blanching in the stock grown in 65 and $80 \%$ shading had positively influenced the rooting ability of cuttings collected from them. These observations corroborate those of Hartmann and Kester (1990), who noted that blanching may favor the action of auxin, and therefore, enhance rooting.

Figure 1. Effect of shading levels on stock plants in the absence or presence of rooting compound and the interaction with length of the longest root (LR).

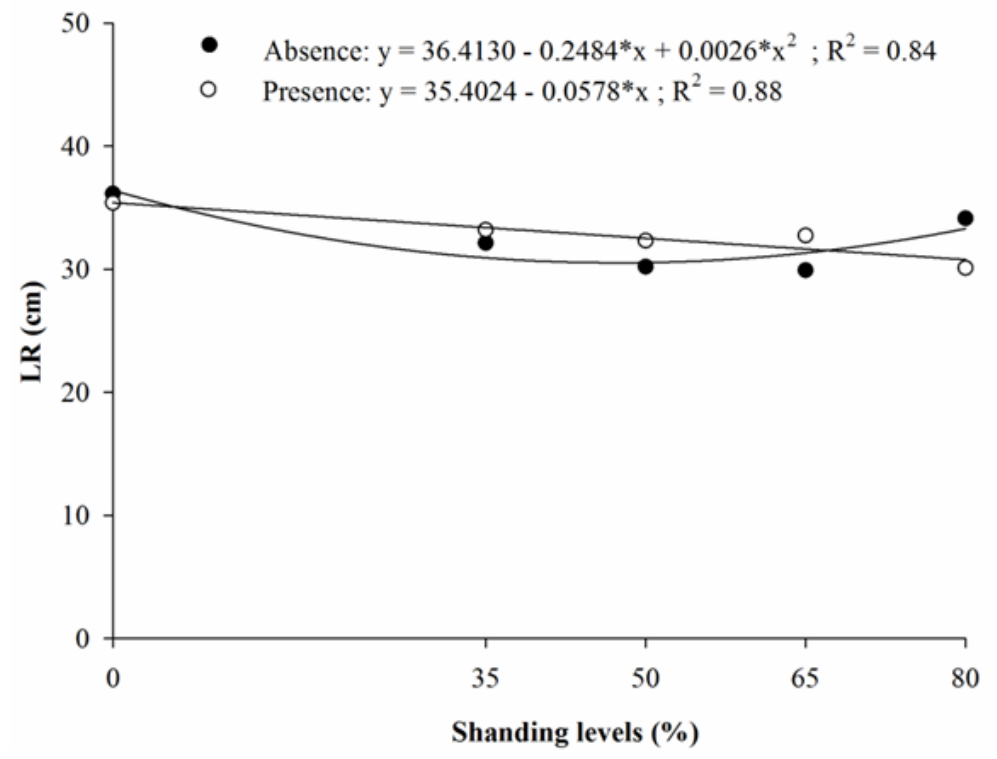

Whereas for the cuttings treated with a rooting compound, LR values decreased concurrently with an increase of shading in the stock plants (Table 4). According to Lone et al. (2010), the increased concentration of exogenous auxin applied to cuttings causes a stimulatory effect of adventitious rooting to a certain maximum value, from which point on it has an inhibitory effect. Therefore, it is likely that the AIB dosage in the commercial rooting compound (3,000 $\mathrm{mg} \mathrm{L}^{-1}$ of AIB) had been excessive and, therefore, caused a negative effect on vertical root growth (LR) (Table 4) and a positive effect on the growth of shoots (SLAS, SDM, SRR) (Tables 7 , $8,10)$. Barroso (2014) also reported negative effects from an AIB dosage of $3,000 \mathrm{mg} \mathrm{L}^{-1}$ on the rooting of vigorous cuttings of red pitaya (45 $\mathrm{cm}$ in length and $43 \mathrm{~mm}$ diameter).

In general, the larger LR was obtained with the use of stock from cladodes grown under full sunlight, regardless of the use of the rooting compound (Figure 1; Table 4). Lima (2013) and Pontes Filho et al. (2014), while studying the effect of cutting length on the rooting of $H$. undatus, stressed that the reserve of carbohydrates is an important factor in the rooting of cuttings. It is likely that in this study, the full sun cultivation condition had been instrumental in increasing the photoassimilated reserves in the cladodes, which positively influenced their rooting capacity. 
Table 4. Absence or presence of rooting compound within each shading level and the interaction with length of the longest root (LR).

\begin{tabular}{cccccc}
\hline \multirow{2}{*}{ Rooting compound } & \multicolumn{5}{c}{ Shading levels on the stock plant (\%) } \\
\cline { 2 - 5 } & 0 & 35 & 50 & 65 & 80 \\
\hline \multirow{2}{*}{ Absence } & $---13 \mathrm{a}$ & $32.13 \mathrm{a}$ & $30.19 \mathrm{a}$ & $29.91 \mathrm{a}$ & $34.13 \mathrm{a}$ \\
Presence & $35.38 \mathrm{a}$ & $33.19 \mathrm{a}$ & $32.31 \mathrm{a}$ & $32.74 \mathrm{a}$ & $30.10 \mathrm{~b}$ \\
\hline
\end{tabular}

Means followed by the same letter in the column did not differ between each other by the Tukey test, at $5 \%$ probability level. dms $=2,89$.

The RDM was increased by the application of the rooting compound, probably due to the beneficial interference of exogenous auxin on the RW (Table 5). That is, the use of a rooting compound induced an increase of RW culminating in the growth of RDM with a positive correlation of $0.78 * *$ (Table 6).
For Betanin and Nienow (2010), the use of growth regulators can be decisive in the rooting process, to accelerate the formation of roots, increase the percentage of rooting, improve the quality of the roots formed, and generate greater uniformity in rooting.

Table 5. Effect of the absence or presence of rooting compound on RW, RDM and SWM.

\begin{tabular}{cccc}
\hline Rooting compound & RW $(\mathrm{cm})$ & RDM $(\mathrm{g})$ & SWM $(\mathrm{g})$ \\
\hline Absence & $11.83 \mathrm{~b}$ & $2.26 \mathrm{~b}$ & $31.89 \mathrm{a}$ \\
Presence & $13.01 \mathrm{a}$ & $3.10 \mathrm{a}$ & $29.47 \mathrm{~b}$ \\
\hline
\end{tabular}

Means followed by the same letter in the column did not differ between each other by the Tukey test, at 5 probability level. dms $=$ 0,55 .

Table 6. Phenotypic Pearson's correlation coefficients $\left(r_{f}\right)$ between characteristics of length of the longest root (LR), root width (RW), root dry mass (RDM), shoot wet mass (SWM), shoot dry mass (SDM), sum of the length of axillary shoots (SLAS), total dry mass (TDM) and shoot:root ratio (SRR).

\begin{tabular}{cccccccc}
\hline Characteristic & RW & RDM & SWM & SDM & SLAS & TDM & SRR \\
\hline LR & 0.16 & 0.28 & -0.15 & -0.40 & -0.24 & -0.15 & -0.47 \\
RW & & $0.78^{* *}$ & -0.02 & -0.04 & -0.10 & 0.07 & -0.10 \\
RDM & & & -0.35 & -0.30 & 0.19 & -0.16 & 0.12 \\
SWM & & & & $0.88^{* *}$ & 0.37 & $0.92^{* *}$ & 0.38 \\
SDM & & & & & 0.54 & $0.95^{* *}$ & 0.60 \\
SLAS & & & & & & $0.74^{*}$ & $0.97^{* *}$ \\
TDM & & & & & & & $0.67^{*}$ \\
\hline
\end{tabular}

** $\mathrm{e} *$, significant at 1 and $5 \%$ level of probability by the $\mathrm{t}$ Test, respectively. The other parameters were not significant.

Regarding the characteristics of the shoots, in plants propagated by cuttings not treated with rooting compound, the shading of the stock at $80 \%$ led to a balanced growth of roots and shoots (Figure
2; Table 7). In this regard, it is possible that the cuttings had rooted with a higher precocity, allowing for better use of water and nutrients in the soil. 
Figure 2. Effect of shading levels on stock plants in the absence or presence of rooting compound and the interaction with the sum of the length of axillary shoots (SLAS).

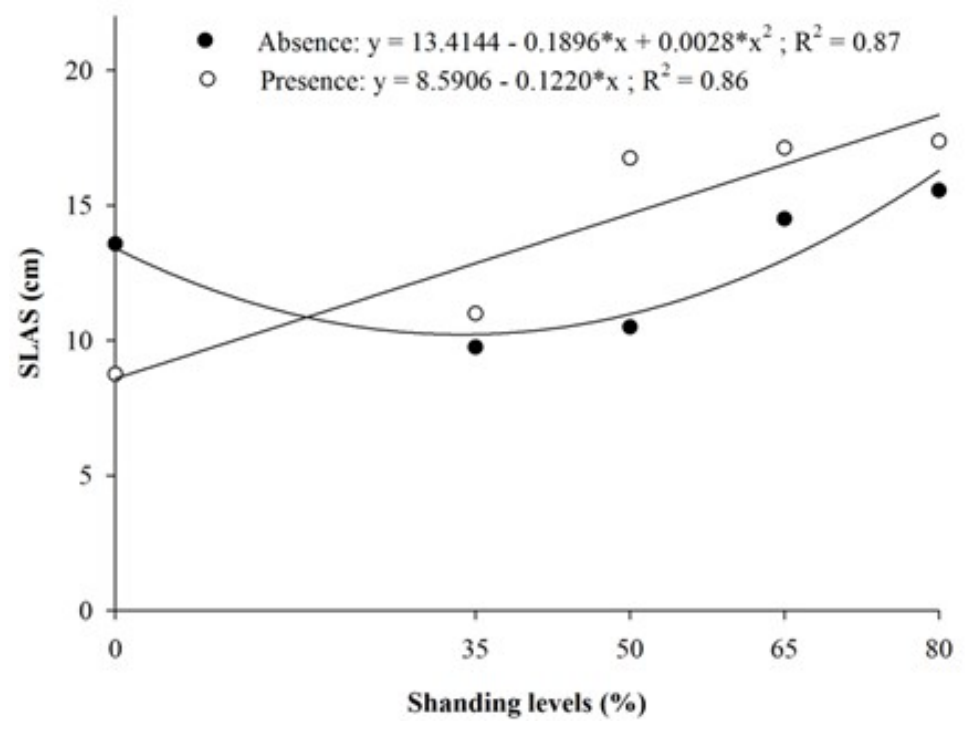

Table 7. Absence or presence of rooting compound within each shading level and the interaction with the sum of the length of axillary shoots (SLAS).

\begin{tabular}{|c|c|c|c|c|c|}
\hline \multirow{2}{*}{ Rooting compound } & \multicolumn{5}{|c|}{ Shading levels on the stock plant (\%) } \\
\hline & 0 & 35 & 50 & 65 & 80 \\
\hline & & ---- & $---\mathrm{cm} \mathrm{-}$ & ---------- & -------- \\
\hline Absence & $13.58 \mathrm{a}$ & $9.75 \mathrm{a}$ & $10.50 \mathrm{~b}$ & $14.50 \mathrm{a}$ & $15.56 \mathrm{a}$ \\
\hline Presence & $8.75 \mathrm{~b}$ & $11.00 \mathrm{a}$ & $16.75 \mathrm{a}$ & $17.13 \mathrm{a}$ & $17.38 \mathrm{a}$ \\
\hline
\end{tabular}

Means followed by the same letter in the column did not differ between each other by the Tukey test, at a level of $5 \%$ of probability. $\mathrm{dms}=2,65$.

The SWM was positively correlated with the $\operatorname{SDM}\left(0.88^{* *}\right)$ and was affected only by the shading of stock plants (Table 6; Figure 3). The means adjusted to a quadratic polynomial model in which the greatest SWM was achieved with the use of cuttings from plants grown under 65 and $80 \%$ shading. This may be related to the blanching of cladodes and the simultaneous increase in the content of endogenous auxin. According to Bastos et al. (2009), in the etiolated branches, there is an increased concentration of endogenous auxin, which reduces the amount of negative cofactors in the rooting process, and consequently can provide better shoot growing capacity. Taiz and Zeiger (2013) substantiated that root growth points are sources of plant growth regulators, especially cytokinin, which are translocated to the shoot growth points and interfere with cell multiplication. In other words, at a desirable threshold of endogenous auxin, both the root system and the shoots experience stimulated growth due to the simultaneous synthesis of cytokinin.

Regarding SDM, the highest values were obtained by using cuttings treated with the rooting compound and collected from stock plants shaded at $80 \%$ (Table 8 , Figure 4 ). This increase of SDM also resulted in a greater TDM $(0.95 * *)$ (Table 9 , Figure 5). Possibly, the use of rooting gel facilitated an excess of endogenous auxin, which induced shoot growth preferentially over that of the root system. However, in the absence of the growth regulator and 
with increased shading of the stock plants, there was a greater balance of SRR with an equitable share of root growth (LR and RDM) and shoot growth (NAS and SDM). The SRR had a direct and positive effect on the TDM $(0.67 *)$ (Table 6).

Figure 3. Effect of shading levels on stock plants on shoot wet mass (SWM).

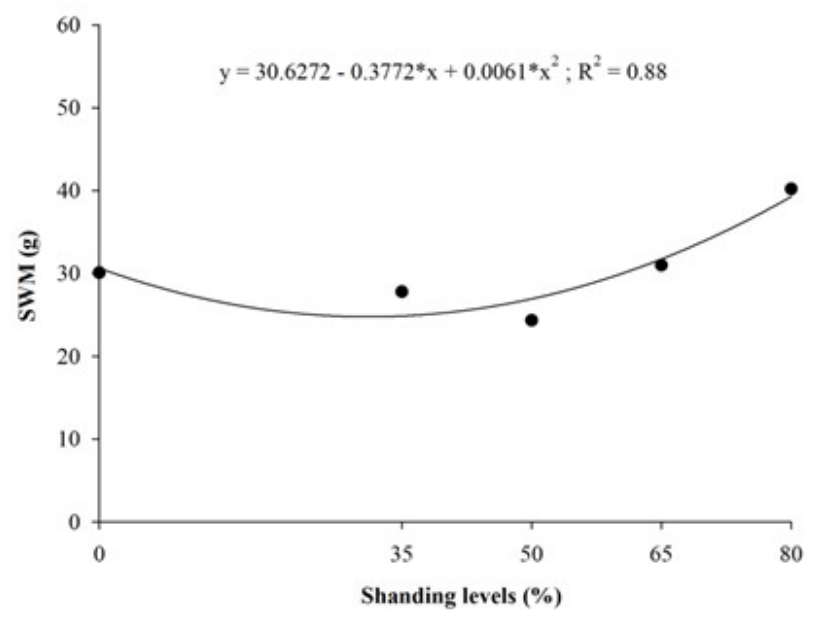

Table 8. Absence or presence of rooting compound within each level of shading and the interaction with shoot dry mass (SDM).

\begin{tabular}{cccccc}
\hline \multirow{2}{*}{ Rooting compound } & \multicolumn{5}{c}{ Shading levels on the stock plant (\%) } \\
\cline { 2 - 5 } & 0 & 35 & 50 & 65 & 80 \\
\hline \multirow{2}{*}{ Absence } & $2.99 \mathrm{a}$ & $2.48 \mathrm{a}$ & $2.63 \mathrm{a}$ & $3.89 \mathrm{a}$ & $3.73 \mathrm{~b}$ \\
Presence & $2.22 \mathrm{~b}$ & $2.83 \mathrm{a}$ & $2.29 \mathrm{a}$ & $2.69 \mathrm{~b}$ & $4.49 \mathrm{a}$ \\
\hline
\end{tabular}

Means followed by the same letter in the column did not differ between each other by the Tukey test, at a level of $5 \%$ of probability. $\mathrm{dms}=0,60$.

Figure 4. Effect of shading levels on stock plants in the absence or presence of rooting compound and the interaction with shoot dry mass (SDM).

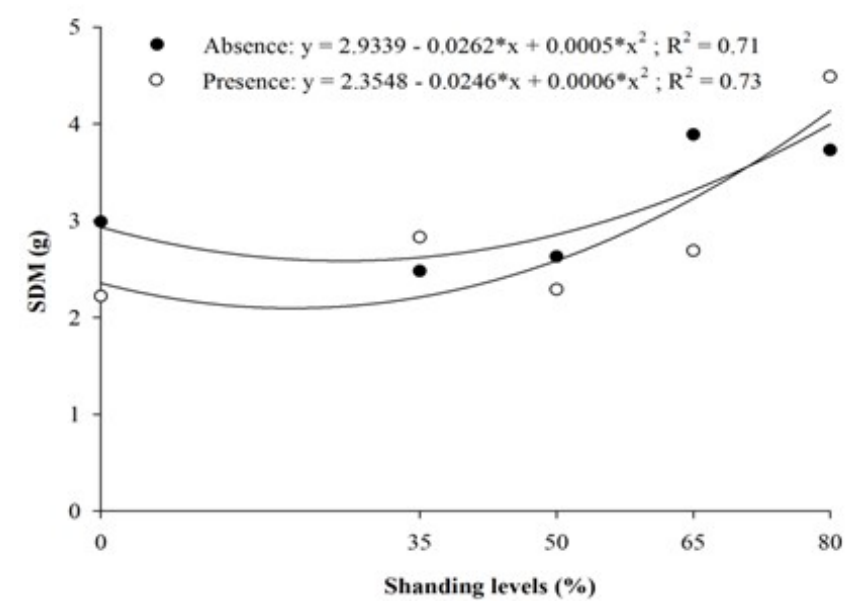


Table 9. Absence or presence of rooting compound within each shading level and the interaction with total dry mass (TDM).

\begin{tabular}{cccccc}
\hline \multirow{2}{*}{ Rooting compound } & \multicolumn{5}{c}{ Shading levels on the stock plant (\%) } \\
\cline { 2 - 5 } & 0 & 35 & 50 & 65 & 80 \\
\hline \multirow{2}{*}{ Absence } & $---12 \mathrm{a}$ & $4.69 \mathrm{~b}$ & $4.77 \mathrm{a}$ & $6.13 \mathrm{a}$ & $5.71 \mathrm{~b}$ \\
Presence & $5.27 \mathrm{a}$ & $6.03 \mathrm{a}$ & $5.22 \mathrm{a}$ & $6.19 \mathrm{a}$ & $7.33 \mathrm{a}$ \\
\hline
\end{tabular}

Means followed by the same letter in the column did not differ between each other by the Tukey, at a level of $5 \%$ of probability. $\mathrm{dms}=0,80$.

Figure 5. Effect of shading levels on stock plants in the absence or presence of rooting compound and the interaction with total dry mass (TDM).

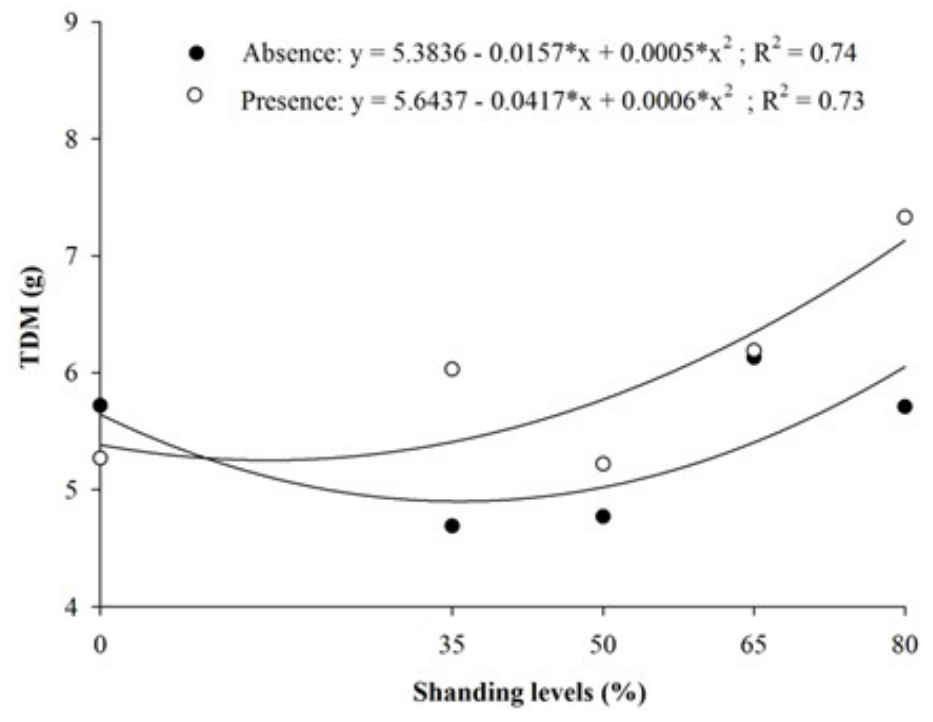

Santos et al. (2010) validate that propagules with well-developed root systems have a lower sensitivity to transplanting and, therefore, have a better chance of survival in field conditions. Thus, the production of red pitaya propagules should prioritize a balanced growth of SRR.

It is important to highlight the satisfactory results for SRR of plants propagated by cuttings not treated with the rooting compound and collected from stock grown in full sunlight (Table
10; Figure 6), which contradicts the hypothesis by Schwengber et al. (2000) for Myrtaceae cuttings grown in full sunlight. According to the authors, high light intensities can activate the AIA-oxidase enzyme system and catalyze the degradation of auxin, leading to a reduction in rooting potential. Therefore, this study validates that although the red pitaya is a semi-epiphytic species, the use of cuttings collected from stock grown in full sunlight allows for the production of high quality plants, eliminating the need to use a rooting compound. 
Table 10. Absence or presence of rooting compound within each shading level (Fortaleza [CE], 2015) and the interaction with shoot:root ratio (SRR).

\begin{tabular}{cccccc}
\hline \multirow{2}{*}{ Rooting compound } & \multicolumn{5}{c}{ Shading level on the stock plant (\%) } \\
\cline { 2 - 5 } & 0 & 35 & 50 & 65 & 80 \\
\hline Absence & $0.38 \mathrm{a}$ & $0.30 \mathrm{a}$ & $0.35 \mathrm{~b}$ & $0.48 \mathrm{a}$ & $0.46 \mathrm{~b}$ \\
Presence & $0.24 \mathrm{~b}$ & $0.33 \mathrm{a}$ & $0.52 \mathrm{a}$ & $0.53 \mathrm{a}$ & $0.58 \mathrm{a}$ \\
\hline
\end{tabular}

Means followed by the same letter in the column did not differ between each other by the Tukey test, at a level of 5\% of probability. $\mathrm{dms}=0,08$.

Figure 6. Effect of shading levels on stock plants in the absence or presence of rooting compound and the interaction with shoot:root ratio (SRR).

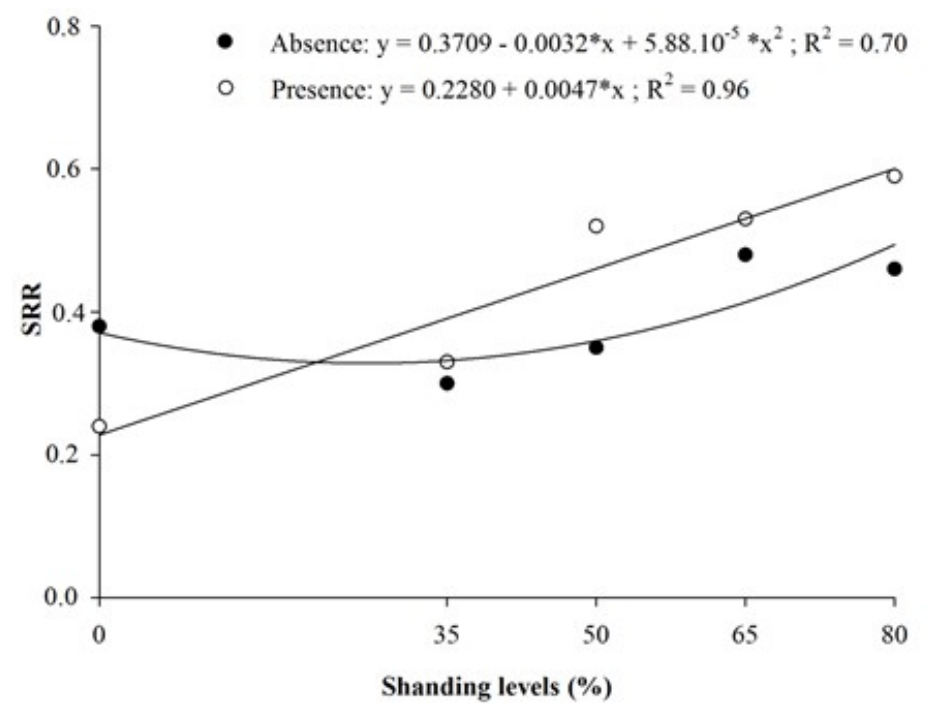

\section{Conclusions}

For the production of good quality propagules, it is recommended to collect cuttings from stock plants of red pitaya grown in full sunlight or $80 \%$ shading. Under these conditions, the use of a commercial rooting compound should be eliminated.

\section{References}

ALMEIDA, E. I. B. Crescimento inicial de pitaia (Hylocereus undatus) em função de combinações de doses de fósforo-zinco e nitrogênio-potássio. 2013. Dissertação (Mestrado em Agronomia) - Centro de Ciências Agrárias, Universidade Federal do Ceará, Fortaleza.

ALMEIDA, E. I. B.; CORRÊA, M. C. M.; CRISOSTOMO, L. A.; ARAÚJO, N. A.; SILVA, J. C. V. Nitrogênio e potássio no crescimento de mudas de pitaia
[Hylocereus undatus (Haw.) Britton \& Rose]. Revista Brasileira de Fruticultura, Cruz das Almas, v. 36, n. 4, p. 1018-1027, 2014.

ANDRADE, R. A.; MARTINS, A. B. G.; SILVA, M. T. H. Influência da fonte e do tempo de cura na propagação vegetativa da pitaia vermelha (Hylocereus undatus Haw.). Revista Brasileira de Fruticultura, Cruz das Almas, v. 29, n. 1, p. 183-186, 2007.

BARROSO, M. M. A. Enraizamento de estacas de pitaia vermelha com diferentes características morfológicas e sob efeito de enraizadores. 2014. Monografia (Trabalho de Conclusão de Curso de Graduação em Agronomia) Centro de Ciências Agrárias, Universidade Federal do Ceará, Fortaleza.

BASTOS, D. C.; PIO, R.; SCARPARE FILHO, J. A.; LIBARDI, M. N.; ALMEIDA, F. P.; GALUCHI, T. P. D.; BAKKER, S. T. Propagação de pitaia vermelha por estaquia. Ciência e Agrotecnologia, Lavras, v. 30, n. 6, p. 1106-1109, 2006. 
BASTOS, D. C.; SCARPARE FILHO, J. A.; LIBARDI, M. N.; PIO, R. Estiolamento, incisão na base da estaca e uso do ácido indol-butírico na propagação da caramboleira por estacas lenhosas. Ciência e Agrotecnologia, Lavras, v. 33, n. 1, p. 313-318, 2009.

BETANIN, L.; NIENOW, A. A. A propagação vegetativa da corticeira-da-serra (Eryhrina falcata Benth.) por estaquia caulinar e foliar. Semina: Ciências Agrárias, Londrina, v. 31, n. 4, p. 871-880, 2010.

CAVALCANTE, I. H. L.; MARTINS, A. B. G.; SILVA JÚNIOR, G. B.; ROCHA, L. F.; FALCÃO NETO, R.; CAVALCANTE, L. F. Adubação orgânica e intensidade luminosa no crescimento e desenvolvimento inicial da pitaya em Bom Jesus-PI. Revista Brasileira de Fruticultura, Cruz das Almas, v. 33, n. 3, p. 970-982, 2011.

CORRÊA, M. C. M.; ALMEIDA, E. I. B.; MARQUES, V. B.; SILVA, J. C. V.; AQUINO, B. F. Crescimento inicial de pitaia em função de combinações de doses de fósforo-zinco. Revista Brasileira de Fruticultura, Cruz das Almas, v. 36, n. 1, p. 23-38, 2014.

DONADIO, L. C. Pitaya. Revista Brasileira de Fruticultura, Cruz das Almas, v. 31, n. 1, p. 1-2, 2009.

DUTRA, T. R.; GRAZZIOTTI, P. H.; SANTANA, R. C.; MASSAD, M. D. Desenvolvimento inicial de mudas de copaíba sob diferentes níveis de sombreamento e substratos. Revista Ciência Agronômica, Fortaleza, v. 43, n. 2, p. 321-329, 2012.

GALVÃO, E. C. Substrato e ácido indolbutírico na produção de mudas de pitaia vermelha de polpa branca. 2015. Dissertação (Mestrado em Agronomia/Fitotecnia) - Universidade Federal de Lavras, Lavras.

HARTMANN, H. T.; KESTER, D. E. Propagacion de plantas: principios y practicas. Ciudad del Mexico: Compañia Editorial Continental, 1990. 760 p.

INSTITUTO DE PESQUISA E ESTRATÉGIA ECONÔMICA DO CEARÁ - IPECE. Estatística e Geografia. Lista mantida pelo IPECE. Fortaleza: IPECE, 2011. Disponível em: <http://www.ipece.ce.gov.br $>$. Acesso em: 10 dez. 2014.

JOHNSON, C. R.; HAMILTON, D. F. Rooting of Hibiscus rosasinensis L. Cutting as influence by light intensity and ethephon. Hortscience, Virginia, v. 12, n. 1, p. 39-40, 1977.

JUNQUEIRA, K. P.; FALEIRO, F. G.; BELLON, G.; JUNQUEIRA, N. T. V.; FONSECA, K. G.; LIMA, C. A; SANTOS, E. C. Variabilidade genética de acessos de pitaya com diferentes níveis de produção por meio de marcadores RAPD. Revista Brasileira de Fruticultura, Cruz das Almas, v. 32, n. 3, p. 840-846, 2010.
KÖPPEN, W. Climatologia: con un estudio de los climas de la tierra. Ciudad del Mexico: Fondo de Cultura Economica, 1918. 478 p.

LE BELLEC, F.; VAILLANT, F.; INBERT, E. Pitahaya (Hylocereus sp.): a new fruit crop, a market with future. Fruits, Paris, v. 61, n. 1, p. 237-250, 2006.

LIMA, C. A. de. Caracterização, propagação e melhoramento genético de pitaya comercial e nativa do cerrado. 2013. Tese (Doutorado em Agronomia) Universidade de Brasília, Brasília.

LONE, A. B.; LÓPEZ, E. L.; ROVARIS, S. R. S.; KLENESER, D. F.; HIGASHIBARA, L.; ATAÍDE, L. T.; ROBERTO, S. R. Efeito do AIB no enraizamento de estacas herbáceas do porta-enxerto de videira VR 43-43 em diferentes substratos. Semina: Ciências Agrárias, Londrina, v. 31, n. 3, p. 599-604, 2010.

MARQUES, V. B.; MOREIRA, R. A.; RAMOS, J. D.; ARAÚJO, N. A.; CRUZ, M. C. M. Profundidade de plantio e dominância apical na estaquia de pitaia vermelha. Semina: Ciências Agrárias, Londrina, v. 33, n. 6, p. 2091-2098, 2012.

Tamanho de cladódios na produção de mudas de pitaia vermelha. Revista Caatinga, Mossoró, v. 24, n. 4, p. 50-54, 2011

MIZRAHI, Y. Vine-Cacti pitayas - the new crops of the world. Revista Brasileira de Fruticultura, Cruz das Almas, v. 36, n. 1, p. 124-138, 2014.

MIZRAHI, Y.; NERD, A. Climbing and columnar cacti: new arid land fruit crops. In: JANICK, J. (Ed.). Perspectives on new crops and new uses. Alexandria: ASHS Press, 1999. p. 358-366.

NOBEL, P. S.; DE LA BARRERA, E. $\mathrm{CO}_{2}$ uptake by the cultivated hemiepiphytic cactus, Hylocereus undatus. Annals of Applied Biology, London, v. 144, n. 1, p. 1-8, 2004.

NUNES, E. N. Q.; SOUZA, A. S. B.; LUCENA, C. M.; SILVA, S. M.; LUCENA, R. F. P.; ALVES, C. A. B.; ALVES, R. E. Pitaia (Hylocereus sp.): uma revisão para o Brasil. Gaia Scientia, João Pessoa, v. 8, n. 1, p. 90-98, 2014.

ORTIZ-HERNÁNDEZ, Y. D.; CARRILLO-SALAZAR, J. A. Pitahaya (Hylocereus spp.): a short review. Comunicata Scientiae, Bom Jesus, v. 3, n. 4, p. 220-237, 2012.

PONTES FILHO, F. T.; ALMEIDA, E. I. B.; BARROSO, M. M. A.; CAJAZEIRA, J. P.; CORRÊA, M. C. M. Comprimento de estacas e concentrações de ácido indolbutírico (AIB) na propagação vegetativa de pitaia. Revista Ciência Agronômica, Fortaleza, v. 45, n. 4, p. 46-51, 2014. 
SANTOS, C. M. G.; CERQUEIRA, R. C.; FERNANDES, L. M. S.; DOURADO, F. W. N.; ONO, E. O. Substratos e regulador vegetal no enraizamento de estacas de pitaya. Revista Ciência Agronômica, Fortaleza, v. 41, n. 4, p. 625-629, 2010.

SCHWENGBER, J. E.; DUTRA, L.; KERSTEN, E. Efeito do sombreamento da planta matriz e do PVP no enraizamento de estacas de ramos de araçazeiro $(P$. cattleyanum Sabine). Revista Brasileira de Agrociência, Pelotas, v. 6, n. 1, p. 30-34, 2000.
SILVA, A. C. C. Pitaya: melhoramento e produção de mudas. 2014. Tese (Doutorado em Agronomia) - Faculdade de Ciências Agrárias e Veterinárias, Universidade Estadual Paulista, Jaboticabal.

SILVA, A. C. C.; MARTINS, A. B. G.; CAVALLARI, L. L. Qualidade de frutos de pitaya em função da época de polinização, da fonte de pólen e da coloração da cobertura. Revista Brasileira de Fruticultura, Cruz das Almas, v. 33, n. 4, p. 1162-1168, 2011.

TAIZ, L.; ZEIGER, E. Fisiologia vegetal. 5. ed. Porto Alegre: Artmed, 2013. 918 p. 